\title{
ZFPM1 Gene
}

National Cancer Institute

\section{Source}

National Cancer Institute. ZFPM1 Gene. NCI Thesaurus. Code C84286.

This gene is involved in transcriptional regulation during erythroid and megakaryocytic cell differentiation. 